\title{
The History and Culture of Idakho People of Western Kenya during Pre-colonial Period
}

\author{
Leen Kavulavu \\ School of Education \& Social Sciences, Department of Humanities, Karatina University, Kenya
}

Copyright $\bigcirc 2017$ by authors, all rights reserved. Authors agree that this article remains permanently open access under the terms of the Creative Commons Attribution License 4.0 International License

\begin{abstract}
This study attempted to broaden our understanding of the Idakho culture during pre-colonial period. The main aim of the research was to examine and unravel the past history pattern, cultural practices of Idakho people, to come up with written reference materials, to promote culture and enhance its contribution to community empowerment. The research used both secondary and primary data derived from field research. On completion, the data of this study has established facts such as determining the historical background of Idakho people and their migration to their first settlement in East Africa and assessed an extent at which the cultural and traditional practices have supported the Idakho community to this date.
\end{abstract}

Keywords Culture, Idakho, Pre-colonial

\section{Introduction}

Many scholars have defined the term culture in different ways. Most definitions describe it as, "the way of life of a certain group of people in a particular society". Were stresses that culture includes norms and values of a society; their religion, political, economic, medicine, marriage rules, songs and dances, laws, eating habits and artefacts" Culture, as Gathogo (2012) observes, is found in all aspects of human life, it shapes a peoples' social life, politics, and their economies All these cultural expressions influence and shape the life of each individual in a society, and in turn an individual makes a cultural contribution to the community through participation in its activities and in some cases through creative work. This paper seeks to illuminate aspects of pre-colonial Idakho history. An attempt is made to trace the migration, settlement pattern and the early history of the Idakho in their present homeland. The relation between the Idakho and their neighbours is also highlighted to show the nature of their interaction during the pre-colonial era. The paper further analyses the Idakho social, political and economic organization before they interacted with western values.

\subsection{Purpose of the Study}

The purpose of this study is to investigate the culture of the Idakho during the pre-colonial period and to examine and unravel the past history pattern, cultural practices of Idakho people, to come up with written references materials, to promote culture and enhance its community empowerment.

\subsection{Significance of the Study}

The findings of the study are beneficial to Idakho community because they know what they have missed from their history. The study established the areas Idakho settled in East Africa and also inspired other people to research on the roots and culture of their people. The study attempts to broaden our understanding of the Idakho culture during pre-colonial period and the findings of the study provides an appropriate community cultural material in an all-inclusive and sustainable manner.

\subsection{Limitation of the Study}

The researcher faced the general problem of time and financial constraints associated with travelling in between data collection point, which limited the scope of the research. Also some respondents were unwillingly to divulge information for their personal reasons.

\section{Research Methodology}

This was a historical study, as a result much of the analysis resolves around primary sources and secondary sources of data. The methodology that was employed for this study is discussed in the subsequent section.

\section{The Study Area}

The Idakho are a Luyia sub-ethnic group that resides in the former Kakamega South district within Kakamega County in Kenya. Kakamega South district was one of the four districts 
curved out of the larger Kakamega District at the start of 2008 that made up Western Province (Republic of Kenya, 2009). According to the 2009 Kenya population and housing census, the population of the district was 104,699 (Kenya National Bureau of Statistic, 2010). Administratively, the district has two sub-counties namely; Ikolomani North and Ikolomani South with six locations and twenty two sub locations. Temperatures are evenly distributed throughout the year with annual temperature ranging from $28^{0}-32^{0}$ (Republic of Kenya, 2009) There are two rainy seasons in the district, the long rains start in March and end in June while the short rains commence in July and end in September with a pick in August. Generally, rainfall varies from $1000 \mathrm{~mm}$ to $2400 \mathrm{~mm}$. The main cash crops grown include tea and sugarcane. Maize, beans, sweet potatoes, finger millet, cassava, bananas, fruits and vegetables are mainly grown as food crops, while livestock rearing is practiced by a few individuals in the district. One of the main rivers found in the district is Yala. It flows westwards through Kakamega forest to the southern part of Kakamega South district. The area has poor physical infrastructure due to heavy rainfall, poor maintenance and low funding (Republic of Kenya, 2009).

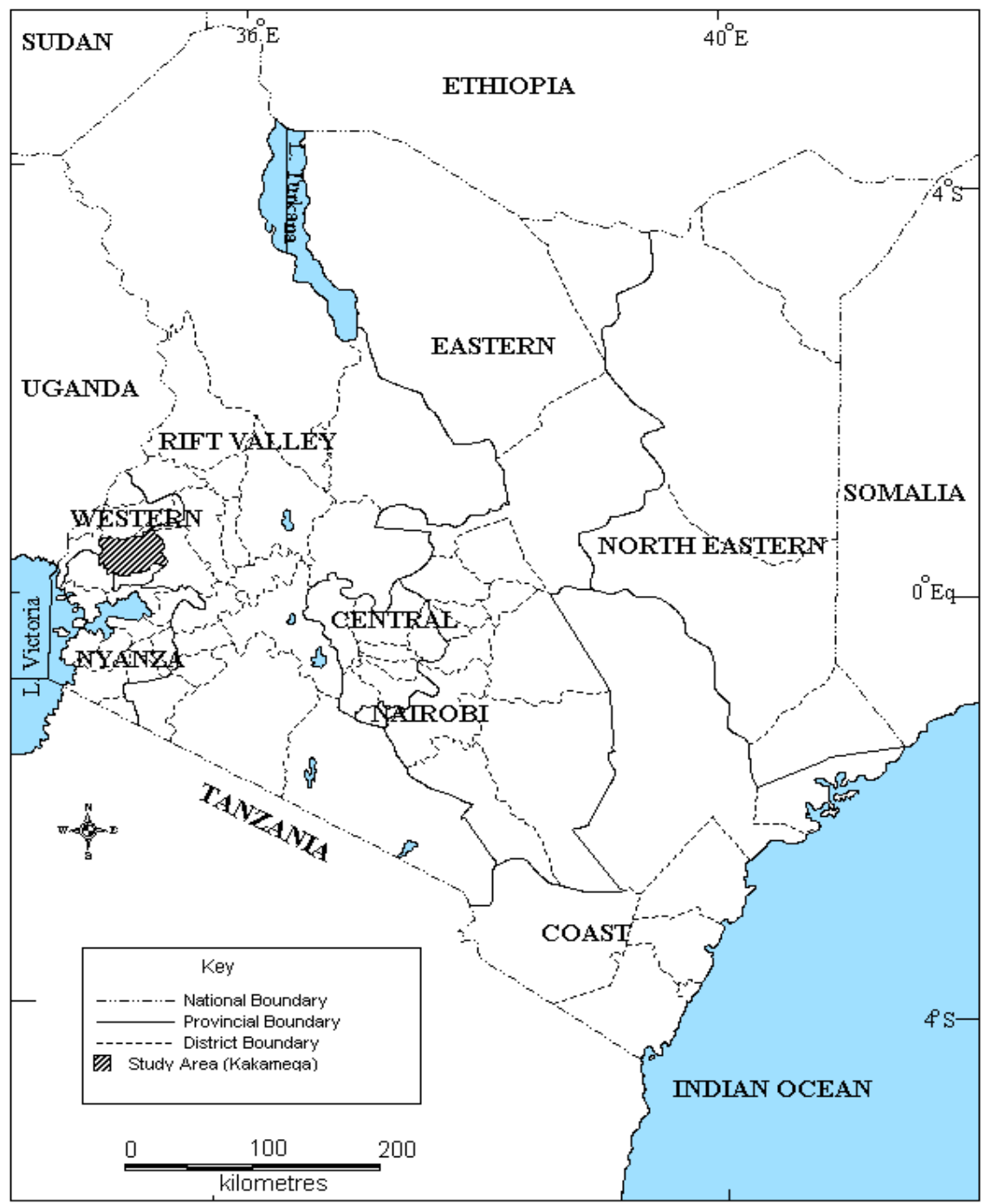

Source: GIS; Geography Department Moi University.

Figure 1. Map of Kenya showing location of study area Kakamega South District. 


\subsection{Sample}

The study was carried out in Kakamega County, Kenya among the Idakho from August to November 2012. The key informants for the study consisted: elders from the Idakho community. These officials were very useful in providing valuable information on the Idakho culture during pre-colonial period. The total sample size was twenty two. During field work the researcher used purposive sampling technique and snowball technique, the researcher identified an elderly informant who knew the area for his great interest in the past of the Idakho culture who in turn directed the researcher to most of the surviving Idakho elders. To deal with the weakness of snowball approach purposive sampling approach was used. In purposive technique people with information on the culture of the Idakho before colonialism were interviewed.

\subsection{Data Collection}

Both primary and secondary sources of data were utilized in this study. The primary sources utilized in this study included oral interviews. The evidence arising from the above documents were analyzed, interpreted and proved useful in enriching secondary sources. Primary data was derived from first-hand information through oral interview conducted by the researcher.

\subsection{Oral Interview}

Semi-structured interviews were used to maximize discussion. The researcher verbally used questionnaires to elicit information from the interviewees by posing the questions. This was because most of them were old and could not read or write in English. Besides note-taking the interviews were recorded on voice recorder and later translated into English language, giving a verbalism account of the conversation with the informants. The questions were easily reframed to encourage free discussions other than just eliciting questions and answers. Oral interview provided an opportunity for cross-checking of the informants to avoid possible misinterpretation and to ensure the understanding of the collected data and hence validity. The method allowed the researcher to understand and capture the informant's oral interview.

\subsection{Data Analysis}

In the analysis of data, the study utilized qualitative data to describe in depth what was on the ground. Oral data collected from questionnaire was compared and contrasted. Once the oral data was organized the researcher cross-checked the information with documentary sources. Through description, comparison and interpretation as methods of analytical discussion, conclusion from data were made in respective stages.

\section{Results and Discussion}

\subsection{Migration and Settlement}

The Idakho as already been pointed out, are one of the Luyia sub- ethnic groups in the present Kakamega County, Kenya. They are part of the Southern Luyia cluster of sub ethnic groups which includes the Isukha, Maragoli, Bunyore and Tiriki as reported by Bode, (1978).Although the Idakho clans speak related languages, have similar pattern of living and enjoyed common cultural practices, there have not been traditional founders and ancestor common to the whole Idakho nor a traditional common alliance which covered the whole Idakho. This is good contrast with the case of the Maragoli as acknowledged by Mwayuuli, (1978). Each Idakho clan has its own peculiar tradition of ancestors and migrations, which suggests that the Idakho have been a congregation of various people who came from all directions and at different times. Each clan is ideally more independent and consider themselves as people of Idakho despite the fact that they are actually different in size. (Enock Shivachi,Oral Interview, September, 12, 2012). The Idakho settlement in Kenya, did not take place all at once, it occurred over a period of time. The clans occupied the area from diverse places and arrived at different times. The people who lived in the area before being occupied by Idakho were small groups of Nandi and Maasai. Were (1974) posits that many of the Nandi and Maasai were therefore forced to migrate to distant places, while those who opted to remain were bantunised and lost their original language and culture. Their descendants variously called Abashimuli, Abamuli, Abashisha, Abashirotsa, Abashikunga, Abakondi and Abashikulu clans that today live in Idakho (Peter Makomele, Oral Interview, September $20^{\text {th }}$ 2012). This is better illustrated by Kizito(1998) when he stated: "For instance, even the layman cannot escape noticing the odd forms of so many place names in this region. For-example (Chirovani, ingolomosio, ileho, lubao, shisaini, iluchecho, kakamega and ididi) which are Maasai and Kalenjin in origin and meaning"). The acculturation process among the groups of Kalenjin as well as the Maasai resulted in various clans that formed the Idakho. From the foregoing, the assertion that the Idakho arrived in one wave of migration is not convincing. They were made up of different clans who came to identify themselves as Idakho people. The migration of the Idakho was enormously influenced by the agricultural potential of the environment. Cognisant of many enemies, the Idakho, therefore, lived in groups and made friends mainly with the Isukha to fight off the Nandi and the Maasai who raided their livestock. In addition they made friends with the Isukha for intermarriage purposes.

Muchanga noted that the Idakho are composed of thirty clans while Mwayuuli noted that the Idakho are composed of fifteen clans. This is contrary to the present evidence derived from oral interviews, informants mentioned 54 clans. It can, therefore, be argued that this must remain largely speculation, 
until more research is carried out regarding Idakho clans. All the informants stated that each clan had its own history of migration and settlement. The clans that were mentioned during oral interview were: Abashimuli, Abamusali, Abashilika, Abakhwang'a, Abakase, Abatula, Abashikulu, Abashiangala, Abashisalachi, Abakhondi, Abamastisti, Abashitsiula, Abammbale, Abanzali, Abakhaya, Abashirikaya, Abandabu, Abasakala, Abashitanyi, Abasichiti, Abamanyisi, Abamachina, Abamalava, Ababukha, Abakwesa, Abasalwa, Abamakambe, Abavyanishi, Abachista, Abalaneshiri, Abashiasuli Abanasio, Abaterema, Ababwanishili, Abamahani, Abanyika, Abasilwa, Abanyishi, Abanyama, Abayila, Abamuhuya, Abashiluka, Abamuli, Abashisha, Abashirosta, Abashikunga, Abamasava, Abamuhali, Abayemi, Abahuli, Abakhubi, Abashitanyi, Abashikanang'a and Abamasungu.

The common clan name bore a rule, of the personal name of the founder of the clan. However, among the Idakho, clans were also named after the women whose sons seceded from their former clan and thus became the founder of the new clan. Wagner (1956) reveals that these clans were named after the woman only if this happened to have been a person of great influence. Among the clans mentioned in this category was Abashimuli.

\subsection{Political Organization}

During pre- colonial days, the Idakho didn't have a chief. The Clan (litala) was therefore an effective political, social and economic unit. Each clan was headed by a clan head whom they referred to as (Omwami) (Lavan Ayuku, Oral Interview, November $11^{\text {th }}$ 2012). A general prerequisite, however, for obtaining leadership among the Idakho was advanced age which was socially marked by the institution of age-mate circumcision rites. It was always the oldest member of a group of kinsmen whose opinion carried the greatest weight on matters concerning that group (John Beti, Oral Interview, September $9^{\text {th }}$ 2012). The authority bestowed by old age was further strengthened by the notions connected with ancestor cult. One of this was that old age was regarded as a necessary condition for officiating at sacrifices. The other notion was that spirits remembered the treatment accorded to them while they were still living persons and that they either haunt and trouble or spare or helped their living relatives according to the treatment received. Old men, therefore, were respected, which considerably added to their authority.

Clan head (Omwami) was expected to encourage unity when legal disputes were discussed by the Idakho elders. When homicides or murder was committed and kinsmen of both parties threatened to go to war, he mediated between the two parties. Another important function of the clan head among the Idakho was to officiate during sacrifices. Moreover, on the occasion of important family sacrifices, the clan head was invited in addition to or in the place of an elder of the lineage. Apart from the clan head, a renowned warrior of the clan was also recognised as a leader, through the reputation gained as a warrior. Their respective successes were measured in terms of the number of enemies killed and the head of cattle raided by them or under their lead. The more a man during his youth or in the prime of his life excelled as a warrior, the more weight his opinion was respected. When later as a clan- elder, he joined in the discussion as to whether a raid should be undertaken, a clanfeud terminated, or an alliance formed with another clan. As long as he was still an active warrior, he could act as a leader in a warfare, but could not yet enjoy any authority in the council of elders. The warrior did not always submit to the wishes and decisions of the old men but at times engaged in raids and wars either without consulting the elders or even against their advice.

Another indispensable condition for attaining a leadership position in the clan among the Idakho during pre-colonial era was through economic status. One who possessed a large herd of cattle, whose granaries were always filled, and who had several wives and retainers that could brew beer and wait on his host, would find enough people to sing his praise, and his homestead became the favourite gathering place of all clansmen, especially the elders. The wealthy man could at any time offer beer to the guests and at frequent intervals serve his guests beef and other delicacies. In addition, a wealthy man gained a more definite influence over some of his clansmen by lending them a goat or a sheep for a sacrifice and a basketful of grains if they ran short of food (Enock Shivachi, Oral Interview, September, 12 ${ }^{\text {th }}$ 2012). Lastly, among the Idakho, a medicine man was also recognised as a clan leader. He was a man who was able to wield a great deal of influence over the people in his clan. In many cases, leadership was handed down from father to son within one clan. The medicine man was a friend to the clan, accessible by everybody and at all times. Mbiti (1969) found that in many cases, medicine person passed on the profession to one of his sons). It was also the duty of the medicine man to purge witches, detect sorcery, remove curses and control the spirits of the dead from doing harm on the living. They had access to the forces of nature and other forms of knowledge unknown by ordinary people. Therefore, the clan entrusted them with the duty of removing what could harm the community. The Medicine man, therefore, symbolized the hopes of good health, protection and security from evil forces, prosperity and good fortunes and ritual cleansing when harm or impurities had contracted the clan., The clan head (Omwami) had a group of advisers called council of elders. The council formed the inner council and assisted the clan head (Omwami) in resolving matters affecting the clan. In most cases, it was the elders (men) who listened to cases and delivered judgment. However, women were only invited to give evidence. Although old women were not directly involved in settling disputes, they were an integral part of the verdict for it was not given before they were consulted. According to Osogo (1965), it, therefore, appears that the actual hearing of cases was a deliberate attempt by the Idakho to massage men's ego when in real sense both men and women agreed on the verdict. 


\subsection{Economic Organization}

The economy of the Idakho in general during pre-colonial era was basically a mixed economy consisting of livestock keeping and crop production. They were at the same time involved in trade, hunting, gathering and handicraft. Land in Idakho, as was the case in general among the Luyia belonged to the clan. This was because whenever a section of land was invaded, the whole clan was expected to defend the land and not to leave it to an individual family. Land allocation was through transmission from father to son. When a father died, his land was handed either to his eldest son or divided among the sons by the clan elders. Usually, while a father was still alive he allocated land to each of his married sons. The remaining land would be allocated to the unmarried sons. Land was basically valued for the purpose of crop production and livestock keeping. It was a means of production. The Idakho valued land because everybody depended on land for survival. Food was derived from land through crop and livestock production. As long as land was abundant in relation to the needs of the occupants, it had no exchange value. Within the clan land, an individual could cultivate any piece of land that had not been cultivated before. The first person to cultivate such a virgin land claimed ownership and would continue cultivating it as long as he wanted. In addition to the clan lands, a major proportion of land in each clan area was designated as communal grazing land and remained reserved for the general use by the community Osogo, (1965).

In pre-colonial Idakho, the agricultural implement used, was a wooden hoe. It was used for clearing the bushes from the field. A new imported iron hoe however came into use in pre-colonial Idakho acquired from the Bunyore, a sub-section of the Luyia (Philip Nabwangu, Oral Interview, September, $17^{\text {th }}$ 2012). The introduction of iron-hoe in Idakho before the imposition of colonial rule expanded agricultural activities. The staple crop that was widely cultivated in Idakho was finger millet (bulee). It was the main dish and was also used to brew traditional beer. In addition, the Idakho also grew sweet potatoes (amabwoni), beans (amakanda), bananas (maremwa), monkey beans (tsimbande) and Cassava (muhoko). The harvest was stored in granary (shiyache) or in a special pot called (isikha). The harvest was reserved for the family to be utilized when food shortages occurred. Maize was probably a recent introduction in the 1890s to the people of Western Kenya as it still had a very limited use. This is well confirmed by Hay study (1972) when point out that when Lord Lugard visited Kavirondo in 1890, he saw "little or no maize. Grant study, argues that travellers to Uganda first noticed the existence of maize in Central Buganda and Bunyore by 1862, in Acholi by 1880 . Thus it seems possible that maize travelled along the main trade routes from Buganda and Bunyoro to Mumias and spread from there into.

Most informants were in agreement that agriculture was the most important economic activity compared to livestock keeping. A study by Wagner (1956) revealed that Luyia were both pastoralists and agriculturalist, however, cattle-keeping was far more important than agriculture in the northern part among the Bukusu while agriculture was more predominant among the southern ethnic groups of the Luyia community Livestock nevertheless played an important role in the economic life of the Idakho. One informant revealed that:

\begin{abstract}
"the slaughter of cattle and smaller stocks formed an important part of ritual occasions such as marriages, funerals or divination ceremonies (John Beti, Oral Interview, September, $20^{\text {th }}$ 2012).
\end{abstract}

In addition, the people of Idakho derived their essential products such as milk, meat and hides from livestock. Apart from providing food, other animal products such as skins were used as clothing and making shields while cattle manure was used for smearing houses. One of the significant uses of livestock in pre-colonial Idakho was for acquiring a wife or wives. Under normal circumstances, marriage involved a complex system of individual transfers of cattle and goats between the two families. Just as Hay's study among the Kowe (1972) demonstrates, cattle were acquired through raiding the enemies The present study regards that the same case revealed among the Idakho who raided their enemies' cattle especially the Nandi or captured them through victory in battles (Enock Shivachi, Oral Interview, September $12^{\text {th }}$ 2012). This study also reveals that among the Idakho cattle accompanied mourners at funerals specifically of respected old men in what they termed as "cattle drive" (shilembe). This was to please the spirit of the deceased while he was not yet in the grave (Enock Shivachi, Oral Interview, September $12^{\text {th }}$ 2012).

Markets developed independently in direct response to the growing needs of the people of Idakho. Informants noted that there were two kinds of trade in pre-colonial Idakho, local trade and regional. Local trade took place among the Idakho clans and with neighbouring Luyia communities such as the Maragoli, Isukha, Kisa, Marama and the Bunyore (Peter Makomele, Oral Interview, September, $20^{\text {th }}$ 2012). Informant observed that regional trade was more active between the Idakho and the Kalenjin from whom they received livestock in exchange for grain, mainly sorghum. (Philip Nabwangu, September $17^{\text {th }}$ 2012). Although hunting and various food gathering activities were practiced, these occupied a comparatively insignificant place in the hierarchy of the economy of the Idakho. Hunting was undertaken by men. These activities were meant to supplement the daily diet. Sometimes men hunted during pre-harvest in order to protect crops from birds and wild animals such as buffalos and elephants. In addition, the Idakho also engaged in pottery that was restricted to the Abasilwa and Abashisalachi clans, who were reluctant to teach it to outsiders for fear of competition.

\subsection{Social Organization}

Among the Idakho, the individual family constituted the basic social group that co-operated most widely and 
intensely in their activities of everyday life. It consisted of a husband, wife, and unmarried children. There was a clearly defined division of duties within the family. Both men and women played a significant role. However, this was only possible if one was married. The woman was partly the coowner of the land that belonged to her husband. It may appear that women did much of the domestic work. This gave women power over the home. Although this was a patriarchal society where men inherited land from their fathers thus accorded them a superior status, There was a clear division of labour between the sexes. Men for instance, cleared virgin land and helped women plant crops while women would weed crops. In essence, the duties carried out by men complemented those done out by women. Men and women needed one another's labour for social production. Table 1 graphically represents some of the gendered responsibilities on the sexes.

Table 1. Division of duties within the family group in Idakho

\begin{tabular}{|c|c|}
\hline DUTIES FOR MEN & DUTIES FOR WOMEN \\
\hline $\begin{array}{l}\text { Hunting, providing security to the } \\
\text { family. }\end{array}$ & Taking care of the home. \\
\hline Clearing the forest & Second digging of the land. \\
\hline Breaking the ground & Weeding \\
\hline $\begin{array}{l}\text { Offering sacrifices on behalf of the } \\
\text { family. }\end{array}$ & Singing on public occasions. \\
\hline In charge of the security. & $\begin{array}{l}\text { In charge of the domestic } \\
\text { chores. }\end{array}$ \\
\hline Negotiating dowry & Asking for brides. \\
\hline $\begin{array}{l}\text { Socialising boys and taking boys for } \\
\text { circumcision. }\end{array}$ & Socialising daughters. \\
\hline $\begin{array}{l}\text { Taking cattle, goats and sheep to the } \\
\text { grazing field. }\end{array}$ & Gathering firewood. \\
\hline Serving chicken & Serving food except chicken \\
\hline Slaughtering an animal. & $\begin{array}{l}\text { Cooking and entertaining } \\
\text { female guests. }\end{array}$ \\
\hline
\end{tabular}

Source: Primary Research.

The outlined gendered division of labour was reinforced by a set of taboos that governed the family unit. The old men were usually useful in oral traditions, narrating stories to the young men. It was also their duty to settle difficult cases especially those involving land ownership and traditional customs. The old women were useful in a similar manner, but they were usually concerned with advising women and girls. It is worth noting that most of the informants acknowledged the fact that the worst curse that one could ever receive came from a woman. This involved a woman, mostly elderly, stripping naked. This act was followed by utterances of condemnation from the women (Noel Nabwangu, Oral Interview, September $17^{\text {th }} 2012$ and Paulina Vinzali, Oral Interview, September $22^{\text {nd }}$ 2012). It was, therefore, every man's desire never to push a woman to that level, be it one's wife or relative. Taboo, therefore, seemed to have existed almost like a constitution among the Idakho. The following are some of the gender- inflicted taboos among the Idakho. It was a taboo:
- For a man to spend time sitting in the kitchen.

- To ridicule an old person.

- For a married man to sweep his own house.

- For a woman to sit on her husband's stool.

- For women to dig a grave.

- For a woman to serve chicken from "the mans" pot".

- For a woman to eat chicken or eggs.

- For a daughter -in-law to take milk to one's father in-law's house.

- For a newly wedded wife to drink sour milk before bearing a child.

- For a woman to milk cows.

- For a woman to visit a witch doctor.

Source: Informants.

These taboos governed the way of life of the Idakho.

Children were trained at an early age to share the duties of family life. At about age six, boys began to herd sheep, goat and cattle, a duty which they outgrew after being circumcised. The girls assisted their mothers in the daily work of fetching water, gathering firewood, wild roots and vegetables and above all, in the weary task of grinding finger millet (bulee).

During pre-colonial period, men used to wear hides and skins. It was passed under the armpit and fastened with a strap- over the opposite shoulder. In addition to skins, the wealthier people put on other items of dress such as shells (emisango). Women used to wear necklace (liboya) made from banana or a goat's skin (shivoya). The necklace was worn around the waist and looked like a kind of apron hanging in front and a tuft of sisal or hair strings hanging behind (Enock Shivachi, Oral Interview, September, $12^{\text {th }}$, 2012). It was a special dress worn by women on occasions of marriage and birth of children. Women also wore bangles (ebitiiri) on their ankles and some wore other rings and wires around their necks or arms. They also liked decorating themselves: some made holes in their ear lobes; they also had tattooed (tsisare) cutting of the body as a sign of beauty. This was done around the waist, at the forehead, abdomen and at the back. Both men and women removed two front teeth (uvula) on the lower jaw for beauty. In a family which had one male child, one of his ears was pierced as a sign of protection and symbolizing the only source of security to his family (Philip Nabwangu, Oral Interview, September $17^{\text {th }}$ 2012).

In pre-colonial Idakho, one of the most cherished rituals was that of male circumcision. This was the single most important event in Idakho and a male had to go through the rituals to be accepted as a member of the community. Those who resisted were initiated by force. The socialization of Idakho boys involved indoctrinating them on the significance of the ritual. An Idakho boy, therefore, grew up knowing that at some stage he would go through the ritual. It was a significant ritual that marked a transition from childhood to adulthood. After initiation, one was allowed to marry, to own property and formed an age group to whom a bond was established that lasted a lifetime. Those initiated 
shared the same knife and this was the single most important symbol of their bond (Inyanza Muhambi, Oral Interview, November $14^{\text {th }}$ 2012). A number of reasons as to why the Idakho initiated their boys as noted by one of the informant was that; it was partly for cleanliness; that initiated boys would be clean at all times. Secondly, Wagner (1956) found that the teachings after the rituals especially in seclusion huts instilled courage to the boys as a symbol of maturity. It prepared boys for war and lastly, it was a time of getting formal education or learning the existential problems of life and how to solve them according to clan customs. Ultimately, it prepared them for marriage. The decision to hold the circumcision rites was taken by the elders of the clan when they saw that sufficient time had passed since the last circumcision for a new generation of young men to have reached the age when they were fit to become warriors. Old men of the community arranged when circumcision would take place.

After the candidates had been ritually prepared by the observance of taboos, by confessions and purification rites and after their morale had been tasted and boosted by singing war songs, they were now ready to undergo the operation. The expert who performed the operation (omushevi) was a man of high social status. Successor to the office of (omushevi) was restricted to his sons. The Idakho operators belonged to the (Abamasava) clan which was said to have held the office exclusively from the distance past. They did not only circumcise all the candidates of their clans, but they also did the same in the neighbouring communities of the Maragoli and the Bunyore who had no operators of their own. The operators were not supposed to amass wealth through the performance of the operation, as they gave away most of the fowls and goats which they were given as tokens for the operation on the candidates. The operator's attire was very much the same among the Luyia sub-groups He dressed in such a way as to appear as fierce and awesome as possible. His face, the upper part of his body, and his arms and legs were painted; round his face he tied a head - dress of colobus monkey skin (enduviri) round the waist a leopard skin and iron rings round his legs. Among the Idakho, the operation was performed in a large open field. It was surrounded by a larger group of onlookers of either sex and all ages who shouted encouraging remarks at them and closely watched for any signs of flinching or faltering (Enock Shivachi, Oral Interview, September $12^{\text {th }}, 2012$ ).

The candidates lined up for the operation in several concentric circles which they formed round a special giant tree (musembe) or (musustu). It gave the youngsters an agegrade (bakhochi) who had been circumcised under it, and it later served as a meeting place for its members. The agegrades provided the bases for social solidarity. The members of various age sets supported one another in everyday activity including courtship and marriage activities. Girls were not circumcised but their ages were known from the age of their husbands. Circumcision was, therefore, part of socialization process in which subtle signals of what constituted good behaviour for both girls and boys were sent out. It was also a time when boys were taught about marriage and other obligations.

An individual who wished to obtain a maximum degree of protection by the community in which he lived and to attain influence and prestige in it aimed at securing for himself a prominent place in the elaborate network of kinship relation. This could only be done through marriage and procreation, for matrimony and parenthood were necessary steps in the process of acquiring status. A bachelor was seen as an incomplete man. A similar, though, milder perception of incomplete man was directed towards childless couples. It was almost an abomination for a woman not to get married. An unmarried woman, who remained in the clan, was a target of hostility even from her own brothers. She had no role or status in the clan and was denied access to certain occasions. Marriage and birth of children were thus occasions for celebrations and festivities (Paulina Vinzali, Oral Interview, September $22^{\text {nd }} 2012$ ). The preparation of marriage started early. As noted earlier, the act of circumcision was one way of preparing boys for ultimate goal of marriage. The choice of a partner was done sometimes through parents or relatives. Sometimes a young man would identify a girl and inform his parents about her. The parents would then start investigations of the girl and later there would be negotiations with the family of the girl. It is notable that it was the boy's mother and aunts who were sent to request for the girl.

As regards marriage, this study shows that similar distinctions were made between persons of the same clan where marriage was ruled out under any circumstances no matter how large the clan and how distant the actual relationship between the two persons concerned. The Idakho were forbidden from marrying into or from the same clan. Taboos existed to reinforce marriage prohibitions. One of the informants pointed out that "children born in a relationship involving relatives would "ripen" like bananas and die" (John Beti, Oral Interview, September $20^{\text {th }}$ 2012). Such a marriage was doomed. Marriage among the Idakho during pre-colonial period, therefore, brought together couples from two different clans. One of the treasured aspects of marriage was virginity. A girl was expected to remain a virgin until she got married. This demand was not put on boys. Great honour was bestowed on the girl and her family if she was found to be a virgin at marriage. Her parents would receive gifts of good will from their son in-law.

Among the Idakho, payment of bridewealth was made to members of the bride's family since the girl had to leave her own clan and be married into another, her family and the clan had therefore lost a useful member (Enock Shivachi, Oral Interview, September $12^{\text {th }} 2012$ ). Cows and bulls were paid as bride wealth in installments. The number of cattle demanded for a girl depended on the number of cattle possessed by the bride's father. Since the Idakho were predominantly agriculturalists, cattle were not in plenty. Therefore, two or three cows were given as bride wealth (Lavana Ayuku, Oral Interview, $11^{\text {th }}$ November 2012). In most cases, therefore, a wealthy man's son married a wealthy man's daughter. While owing to the territorial grouping of 
clans the people who intermarried were only in expectation cases close neighbours. The bridewealth was therefore an important custom for it not only sealed the marriage bond, but also distinguished the man as a dignified member of the community. If at all the woman died before bridewealth was paid to her parents, her body was taken back to her parents' home (Philip Nabwangu, Oral Interview, September $17^{\text {th }}$ 2012). The groom's parents made part of the payment of bridewealth to the brides' family at the time of the marriage. This underscored the fact that the girl got married into the clan and not to an individual. The girl was, therefore, not perceived as a market commodity or a slave. The payment was taken as an appreciation for the gift of the new member of the family (John Beti, Oral Interview, September $20^{\text {th }}$ 2012). The cows were in turn used by the girls' family to finance the marriage of their sons. This made the girl to be appreciated by her brothers, since they facilitated their marriage. Once the full contract of marriage was executed, it was extremely difficult to dissolve it. There were, however, few instances in which divorce was sanctioned. For instance, if a woman was a witch this meant that the woman would endanger the life of her husband. In case of sterility on the part of the husband, another man was asked to sire children for him. If the woman was barren, the man married a second wife for the purpose of producing children but retained the barren wife (Enock Shivachi, Oral Interview, September $12^{\text {th }}$ 2012). Polygamy was a common practice among the Idakho during pre-colonial period. To some extent, it was perceived as having to do with giving security to the man. Another reason advanced in support of polygamy was that a man's wealth was measured in terms of the number of wives, children or livestock he had (John Beti, Oral Interview, September, 20 ${ }^{\text {th }}$ 2012). A man who was wealthy was respected. It was, therefore, prestigious to have many wives. Wife inheritance was one of the cherished institutions among the Idakho. A woman once married belonged to the clan. The death of the husband in some sense loosened the ties that bound the woman to the clan. A clan member or an age mate to the deceased husband was asked to inherit the woman. Thereafter, elaborate rituals were performed (Enock Shivachi, Oral Interview, September, 12 $2^{\text {th }} 2012$ ).

The person who died left one "phase" of his existence to enter another not only as regards his own individual existence, but also as regards the place they occupied among the living. The Idakho performed many complicated ceremonies connected with death and burial. When one died, people wailed, and beat drums. The body of a dead person was kept inside the house for a day. The body was laid on an animal skin and covered with a skin or with banana leaves, and if it was a prominent man, a leopard skin was used. Neighbours and relatives brought beer and food, some played musical instrument, and others sung funeral songs and dances. Mbiti (1969) indicate that this was intended partly to appease the spirit of the dead person and partly to comfort the bereaved family. The procedure followed when burying a person showed a number of variations according to the sex, age and social status as well as certain peculiarities of the deceased. Among the Idakho, the burial of an ordinary person took place the next day, so that there was one full night for keeping the body and to permit even those of his relatives who lived far away to come and view the body before burial. Elders of higher social status were buried on the second or third day. And in the case of a clan head and clan leaders, the burial was delayed until the fourth day (Edward Okang'a, Oral Interview, November 18 ${ }^{\text {th }} 2012$ ). Such a delay was founded on the belief that it would appease the spirit of the deceased to remain in the company of the living as long as possible, so that he may see the mourners and watch the performance of the "cattle drive" (shilembe) and the mock fight before he could be buried (Philip Nabwangu, Oral Interview, September 17 $7^{\text {th }}$ 2012). During the ceremony of "cattle drive" (shilembe) cattle were gathered and decorated with weeds or grass, people painted their faces with white clay and adorned war gear for instance hides, leopard skins or grasses, and carried spears, clubs, shields and sticks. The songs that were sung included war songs, marriage songs, dirges, that praised the deceased and appreciated the contribution he made to the clan. This ceremony was intended to drive away the spirit of the dead man, so that it did not linger around the homestead as to cause misfortunes. Infants and small children on the other hand, were usually buried a few hours after they had died, a custom which was in accordance with the prevailing notion that spirits of children were "powerless" and that it was therefore unnecessary to take much trouble over them.

The Idakho evolved an elaborate form of worship through ancestors that proved by far the most important part in their religious lives. The Idakho religion recognized the power of ancestral spirit in their cosmology. Sacrifices involved a white male goat with horns. The rituals were presided over by the traditional diviner. The elders then roasted and ate the whole meat. It was, however, notable that the elders were men and not women. Members of the various clans made sacrifices to the ancestors beseeching them to solve societal problems. On such occasions, sacrifices were for purposes of appeasing the clan's ancestral spirits who were believed to be unhappy, because of wrong doing in the society or for being neglected. The clan elders took their spears and visited the graves, of the clan heroes. They observed a commemoration, which involved singing and dancing in praise of the ancestors (Lavan Ayuku, Oral Interview, November $11^{\text {th }}$ 2012). The Idakho religion recognized the power of the ancestral spirits in their cosmology. They venerated this spirit to promote good health and the welfare of the community and family. The veneration of the Idakho ancestor at the family level centered on three sacrificial stones. The stones were about a foot high and stuck in the ground so that they formed a triangle. On all important occasions in the life of an individual from birth to death, the sacrificial stones (musabwa), constituted the centre of their relationship with the living dead. On such occasions, relatives met to offer sacrifices. The stones were placed only in homes of married men with children. The Idakho, therefore, believed in the existence of God approached by 
men through the medium of spirits of the dead to whom private respect was paid.

\section{Conclusions}

It is worth noting that culture research is a tedious undertaking exercise that Kenya has not performed well in the development of creative cultural industries. This may be attributed to lack of a strong human financial and material resource base that is required to facilitate the support and full development of the culture sector. The problems facing many citizens are largely based on the erosion of the values as a society. The researcher introduces Idakho culture and tradition and takes the reader through the paper that seeks to encourage and inspire people on the importance of African cultural values. The paper has attempted to discuss the Idakho society during pre-colonial period. It has shown the migration pattern of Idakho and how they settled in their area. The main focus has been on the review of their political, economic and social organisation. The whole process of these organisations was very important as it is these levels that indigenous culture reached its highest degree of its consciousness. The study has demonstrated the dynamism of the Idakho by showing that through interaction with the physical environment; it adopted elements which enriched its culture. The process was accelerated by interaction with neighbouring communities. Here, it has been shown that the community both rejected and borrowed cultural values, beliefs and practices from their neighbours depending on whether they endangered or enhanced the integrity of the society.

\section{REFERENCES}

[1] Bode,F.C., (1978). Leadership and Politics among the Abaluhyia of Kenya. Ph.D. Thesis, Yale University

[2] Gathogo, J.M. The Relevance and Influence of African Religion in Post-Apartheid South Africa and Beyond. Retrieved from

http://www.churchsociety.org/Cman_121_2_Gathogo.pdf, Assessed on June 252012.

[3] Hay,M.J. (1972). Economic Change in Luo Kowe 1890-1945. Doctor of Philosophy History, University of Wiscons.

[4] Mbiti,J.S. (1969), African Religion and Philosophy. Nairobi, Kampala, Dar es salaam, Kigali: East Africa Educational Publisher.

[5] Muchanga, K. (1998), Impact of economic activities of the ecology of the Isukha and Idakho areas of Western Kenya C.1850-1945. M.A. Thesis, Kenyatta University.

[6] Mwayuuli,M.S. (1978), The History of the Isukha and Idakho clans among the Abaluyia of Western Kenya. Nairobi: Kenya Literature Bureau.

[7] Osogo, J. (1965) Life in Kenya in the olden days. Nairobi: East Africa Educational Publisher.

[8] Republic of Kenya, (2009). Kakamega South District Development Plan 2008-2012.Nairobi Government Printer.

[9] Republic of Kenya, (2010). Kenya National Bureau of statistics, The 2009 Kenya population and Housing census. Volume 1A population Distribution by Administrative units. Nairobi: Government Printer.

[10] Wagner,G. (1956), The Bantu of North Kavirondo Vol.11. London, New York, Toronto: Oxford University Press. 